\title{
Rendering Fat and Heavy Fischer-Tropsch Waxes Mixtures $(0-100 \%)$ Fast Pyrolysis Tests for the Production of Ethylene and Propylene
}

\author{
Martyna Murat ${ }^{1}{ }^{\circledR}$, Zahra Gholami ${ }^{1}{ }^{\circledR}$, Josef Šimek ${ }^{1}$, Daily Rodríguez-Padrón ${ }^{2}$ \\ and José Miguel Hidalgo-Herrador ${ }^{1, * \mathbb{D}}$ \\ 1 ORLEN UniCRE a.s., Revoluční 1521/84, 40001 Ústí nad Labem, Czech Republic; \\ martyna.murat@unicre.cz (M.M.); zahra.gholami@unicre.cz (Z.G.); josef.simek@unicre.cz (J.Š.) \\ 2 Department of Organic Chemistry, Campus de Rabanales, University of Cordoba, Edificio Marie Curie (C-3), \\ Ctra Nnal IV-A, Km 396, E14014 Cordoba, Spain; dailydggs@gmail.com \\ * Correspondence: jose.hidalgo@unicre.cz
}

check for updates

Citation: Murat, M.; Gholami, Z.; Šimek, J.; Rodríguez-Padrón, D.; Hidalgo-Herrador, J.M. Rendering Fat and Heavy Fischer-Tropsch Waxes Mixtures (0-100\%) Fast Pyrolysis Tests for the Production of Ethylene and Propylene. Processes 2021, 9, 367. https://doi.org/doi:10.3390/ pr9020367

Received: 27 January 2021

Accepted: 11 February 2021

Published: 17 February 2021

Publisher's Note: MDPI stays neutral with regard to jurisdictional claims in published maps and institutional affiliations.

Copyright: (c) 2021 by the authors. Licensee MDPI, Basel, Switzerland. This article is an open access article distributed under the terms and conditions of the Creative Commons Attribution (CC BY) license (https:// creativecommons.org/licenses/by/ $4.0 /)$.

\begin{abstract}
A great emphasis is placed on searching for efficient sources to produce renewable fuels due to the actual trends in avoiding the use of fossil resources to mitigate the environment's deterioration. Thus, the use of waste from the food or wood industry for the production of biofuels is widely researched and may contribute to sustainable general development. Rendered fat and FischerTropsch waxes are high-energy materials which could be used for the pyrolysis reaction. Therefore, in this study, the effect of reaction parameters and feedstock composition on the distribution of the pyrolysis products has been examined. The experiments were carried out in a nitrogen atmosphere in a multi-shot pyrolizer instrument equipped with GC-FID. First, the influence of the temperature was examined at 785,800 , and $815^{\circ} \mathrm{C}$. The highest yield to olefins was observed at $815^{\circ} \mathrm{C}$. The effect of triglycerides and paraffins contents $(0-100 \%$ with $10 \%$ ramp) in the feedstock on the product composition was investigated at $815^{\circ} \mathrm{C}$. The gas chromatography analyses revealed that the feedstock composition did not significantly affect the product composition due to the high temperature and the long linear chain structure similarities between the free fatty acids and Fischer-Tropsch waxes.
\end{abstract}

Keywords: pyrolysis; rendering fat; ethylene; propylene; Fischer-Tropsch

\section{Introduction}

Resources depletion and environmental pollutions, carbon emissions, and global warming issues caused by using fossil fuels are among the most significant challenges in the 21st century and increased the interest in exploring alternative energy and fuel sources, as well as reducing fossil fuel dependency. A decrease of $80-95 \%$ in the greenhouse gas (GHG) emission by 2050 has been committed by the EU in accordance with the necessary reductions by developed countries as a group [1]. In order to increase the use of renewable energy in the gross final energy consumption in Europe, the renewable energy directive (RED) commits the EU member states to increase the share of renewable energy to $20 \%$ of the gross final energy consumption, and also reach a $10 \%$ share of renewable energy in the energy used in transport by 2020 [2]. There are different scenarios for lowering the global fossil fuel demands, significantly depending on finalizing a global climate deal. One of the decarburization scenarios is the increase in renewable energy resources, increasing the share of renewable energy to $75 \%$ of the gross final energy consumption, and also reach a $97 \%$ share in electricity consumption in 2050 [1]. It has been expected that by 2050 renewable energy will be the leading source of the primary energy consumption [3]. However, fossil fuels still continue to meet a large portion of the world's energy demand. According to the predictions, the share of petroleum and other liquids decreases from $32 \%$ in 2018 to $27 \%$ in 2050 . However, on an absolute basis, the consumption of liquids increases 
in the commercial, industrial, and transportation sectors and decreases in the electric power and residential sectors.

Steam cracking is an industrial way to produce ethylene and propylene. In more detail, steam cracking is one of the most important processes to produce basic petrochemical commodities producing not only propylene and ethylene but also hydrogen, methane, light olefins, butenes, butadiene, cyclopentadiene, isoprene, and aromatics [4]. Olefin plants in the industry are used for the production of ethylene and propylene, the main feedstocks for polyolefins production, which account for $50-60 \%$ of all commercial organic chemicals [5]. Nevertheless, the feeds used for this purpose are fossil resources (primary naphthas, natural gas condensates, and liquid petroleum gases). Based on the composition of the feedstock and reaction conditions, the products of steam cracking contain $10-35 \mathrm{wt} \%$ of ethylene, 5-20 wt\% of propylene, 1-15 wt\% of C4 fractions, mainly butadiene and butenes, $1-10 \mathrm{wt} \%$ of aromatics, mainly BTX: Benzene, toluene, and xylene), and 0-15 wt $\%$ of heavy hydrocarbons (pyrolysis oils) [6]. In addition to the traditional oil-based stocks, other stocks are of interest for the olefin production. For example, Fischer-Tropsch (FTS) waxes with high paraffinicity, produced from the biomass gasification or ethane reforming, would be a good candidate for this purpose [7]. Hydrotreated pyrolysis oils were also reported as another feedstock in FCC, with low selectivity to light olefins [8]. Several studies have been carried out for a considerable increase in ethylene production, and the use of biomass and waste stream for olefin production has become more promising and attracted more attention. Therefore, a more environmentally friendly feedstock is needed for the production of these chemical commodities in the industry.

The concept of a flexible industrial conglomerate is being used nowadays, and it refers to the use of refinery units to produce fuels and the use of petrochemical units to produce other chemical compounds [9]. The respective production of fuels or chemical commodities is carried out according to the market demands. This point referred to a renewable refinery-petrochemical conglomerate that would need renewable feedstocks. One of these feeds could be free fatty acids, mono, di-, and triglycerides, which could be previously hydrodeoxygenated to produce fuels (gasoline, diesel range) or directly used to produce other chemical commodities such as ethylene or propylene. In addition, depending on the market demands, the deoxygenated products from free fatty acids, mono, di-, and triglycerides could also be pyrolyzed to other useful products for the company. Therefore, the use of triglycerides or their HDO products for refinery or petrochemistry is a flexible concept of renewable processing. If the renewable feedstock is also a waste (non-edible), it is considered as a more suitable feedstock for the production of ethylene or propylene. Concretely, the rendering fat (RF) can be used as a non-edible waste feedstock, which can be produced from the waste of slaughterhouses and carcasses of livestock [10].

Moreover, the FTS feedstock can be considered as a renewable source to be used for the production of ethylene and propylene [11]. However, the respective range of boiling temperatures fractions of this feedstock can be used to produce fuels such as gasoline, diesel, kerosene, or jet fuels, which could be considered as more suitable products depending on the market demands. The use of a heavy FTS fraction to produce fuels needs the extra cracking reaction to produce a lighter range of boiling temperatures fractions. Therefore, its use as a feedstock for steam cracking could be an advantage. These heavier FTS fractions have a high potential added value [11-15].

In this work, the use of FTS heavy fraction paraffins, HDO paraffins from RF, and RF for the production of ethylene and propylene using fast-pyrolysis have been examined. The methodology used took into account previous methodologies and publications [16-21]. The response surface methodology (RSM) was used with FTS and HDO paraffins. In addition, FTS and animal fat mixtures were tested at different ratios with the aim of studying the production of ethylene and propylene. RSM was a useful tool to have more information on the content of the products after pyrolysis tests. The adding of RF to the feedstock for the pyrolysis tests led to similar results compared to the pure FTS pyrolysis tests. 


\section{Materials and Methods}

Waste RF and FTS paraffins with a boiling point $>340{ }^{\circ} \mathrm{C}$ were used [10].

The nitrogen carrier gas for the pyrolysis tests supplied by the Linde company (nitrogen 5.0 with a purity $\geq 99,999 \%)$ was used in the system for the pyrolysis $(64.5 \mathrm{Nl} / \mathrm{min})$.

The simulated distillation (SIMDIS) of the raw materials was carried out using the ASTM D7169 methodology (the American Society for Testing and Materials-Standard Test Method for Boiling Point Distribution of Samples with Residues Such as Crude Oils and Atmospheric and Vacuum Residues by High Temperature Gas Chromatography).

The waste RF was already used (as feedstock) in other research work [10]. For the experiments in this work, the feedstock was analyzed (metal and elemental C, H, N, S analyses) as shown in Table 1.

Table 1. Metals and elemental C, H, N, S, O percent (oxygen calculated by difference) and ash composition for the rendering fat $(\mathrm{RF})$.

\begin{tabular}{|c|c|c|}
\hline Metal Composition & Amount & Units \\
\hline $\mathrm{Al}$ & $<0.4$ & $\mathrm{mg} \mathrm{kg}^{-1}$ \\
\hline $\mathrm{Ca}$ & 110 & $\mathrm{mg} \mathrm{kg}^{-1}$ \\
\hline $\mathrm{Cr}$ & 6.38 & $\mathrm{mg} \mathrm{kg}^{-1}$ \\
\hline $\mathrm{Fe}$ & 13.3 & $\mathrm{mg} \mathrm{kg}^{-1}$ \\
\hline $\mathrm{K}$ & 218 & $\mathrm{mg} \mathrm{kg}^{-1}$ \\
\hline $\mathrm{Mg}$ & 16.6 & $\mathrm{mg} \mathrm{kg}^{-1}$ \\
\hline $\mathrm{Mn}$ & $<0.2$ & $\mathrm{mg} \mathrm{kg}^{-1}$ \\
\hline $\mathrm{Na}$ & 216 & $\mathrm{mg} \mathrm{kg}^{-1}$ \\
\hline $\mathrm{Ni}$ & $<0.2$ & $\mathrm{mg} \mathrm{kg}^{-1}$ \\
\hline $\mathrm{P}$ & 50.1 & $\mathrm{mg} \mathrm{kg}^{-1}$ \\
\hline $\mathrm{Ti}$ & $<0.2$ & $\mathrm{mg} \mathrm{kg}^{-1}$ \\
\hline $\mathrm{C}$ & 76.6 & $\mathrm{wt} \%$ \\
\hline $\mathrm{H}$ & 12.3 & $\mathrm{wt} \%$ \\
\hline $\mathrm{S}$ & - & $\mathrm{mg} \mathrm{kg}^{-1}$ \\
\hline $\mathrm{N}$ & 800 & $\mathrm{mg} \mathrm{kg}^{-1}$ \\
\hline Oxygen by difference & 11.0 & wt $\%$ \\
\hline Ash content ${ }^{1}$ & 0.3 & $w t \%$ \\
\hline Acid value $^{2}$ & 65.5 & $\mathrm{mg} \mathrm{KOH} \mathrm{g}^{-1}$ \\
\hline Water content & 2650.3 & $\mathrm{mg} \mathrm{kg}^{-1}$ \\
\hline
\end{tabular}

${ }^{1}$ The ash content was calculated by TGA in oxygen from 50 to $900{ }^{\circ} \mathrm{C}, 10^{\circ} \mathrm{C} / \mathrm{min} .{ }^{2}$ Milligrams of $\mathrm{KOH}$ added to $1 \mathrm{~g}$ of $\mathrm{RF}$ to obtain a $\mathrm{pH}$ value of 7 .

The TGA analysis (Table 1) was performed using a TA Instruments Waters LLC instrument from 50 to $900{ }^{\circ} \mathrm{C},\left(10^{\circ} \mathrm{C} \mathrm{min}^{-1}\right)$ using oxygen as a gaseous carrier. The simulated distillation (SIMDIS) results of the three feedstocks used for the fast pyrolysis tests is displayed in the Figure 1.

The main products in the organic phase were free fatty acids (FFA), as shown in Figure 1 (range of boiling temperatures $340-420^{\circ} \mathrm{C}$ ). The SIMDIS was calibrated, and as shown in a previous work ${ }^{7}$, the range of boiling temperatures of $50-220^{\circ} \mathrm{C}$ was related to $C_{5}-C_{12}$ compounds, $220-340{ }^{\circ} \mathrm{C}$ to $\mathrm{C}_{12}-\mathrm{C}_{19}$ compounds, $340-420{ }^{\circ} \mathrm{C}$ was mainly related to the free fatty acids and $\mathrm{C}_{20+}$ compounds, and the range of boiling temperatures above $420^{\circ} \mathrm{C}$ was related mainly to mono, di-, and triglycerides.

The feedstock of the paraffins, obtained after the hydrodeoxygenation reaction (HDO), was obtained previously [22] and stored in a fridge for 1 year. The feedstocks were analyzed again (SIMDIS), and the properties were unchanged and almost identical as shown in a previously published work. For this feedstock, in the SIMDIS (Figure 1), four main increments of the amount distilled at $270,286,305$, and $318^{\circ} \mathrm{C}$ were shown, which were related to $\mathrm{C}_{15}-\mathrm{C}_{18}$ hydrocarbons, respectively (ref). 


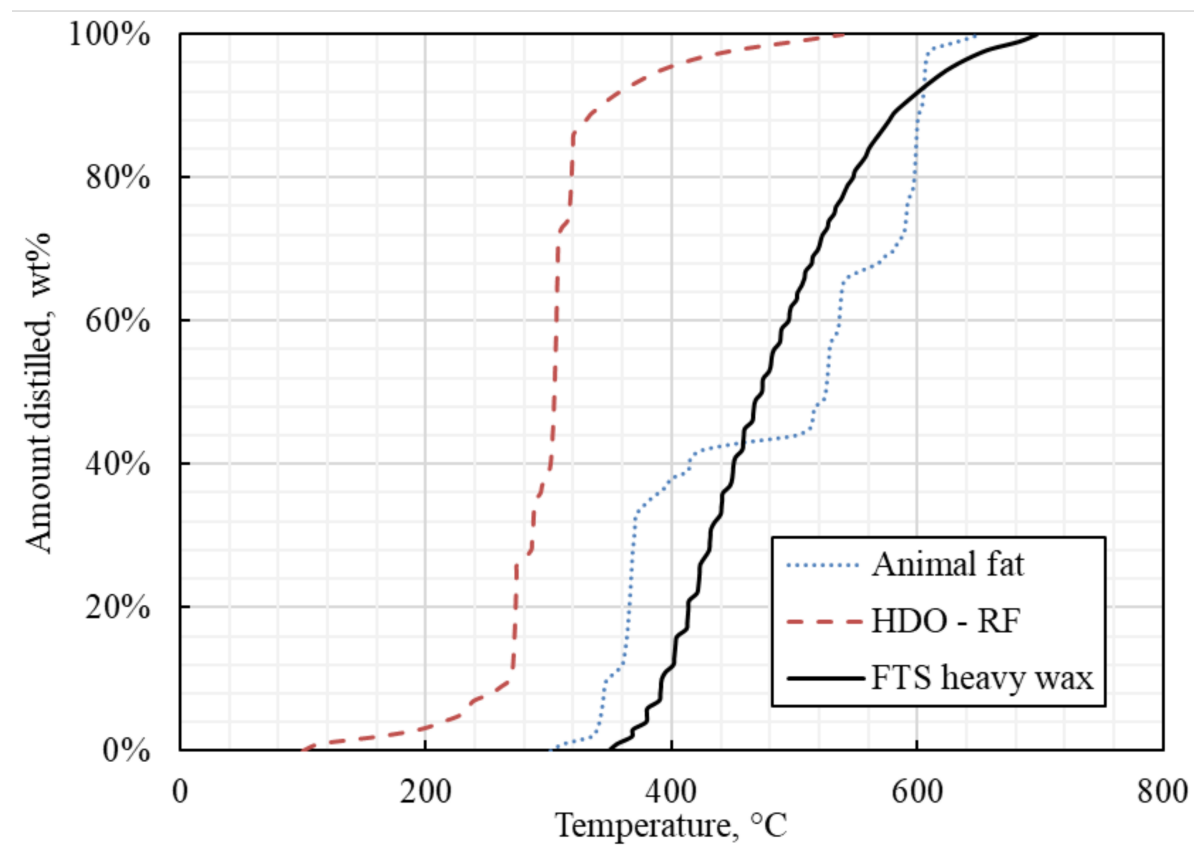

Figure 1. The SIMDIS of the three feedstocks used for the fast pyrolysis tests. The animal fat, the paraffins from the hydrodeoxygenation (HDO) reaction of this animal fat (HDO-RF text in the picture), and the Fischer-Tropsch (FTS) heavy fraction waxes (FTS heavy wax) are displayed in the figure.

FTS paraffins were used as feedstock (Figure 1, Tables 2 and 3). The compounds started to be distilled at a boiling point of $350{ }^{\circ} \mathrm{C}$ approximately. The heavy fraction of FTS products was selected with the idea of its co-processing with animal fat, taking into account a scene in which a refinery has an excess content of heavy residues of FTS and it needs the flexibility of using them to produce ethylene and/or propylene. Thus, the flexible concept of renewable sources to fuels or chemicals (monomers ethylene and propylene) depended on the market demands. This concept is similar to the actual one based in the Refinery-Petrochemistry flexible system using fossil crude oil as feedstock.

Table 2. SIMDIS data for FTS waxes used for pyrolysis.

\begin{tabular}{ccc}
\hline Amount Distilled, wt $\%$ & Temperature, $^{\circ} \mathbf{C}$ & $\mathbf{n C x}$, (n-alkanes) \\
\hline Initial Boiling Point & 348.34 & $\mathrm{nC}_{20}$ \\
$1 \%$ & 355.16 & $\mathrm{nC}_{21}$ \\
$5 \%$ & 379.39 & $\mathrm{nC}_{22}-\mathrm{nC}_{23}$ \\
$10 \%$ & 391.36 & $\mathrm{nC}_{24}$ \\
$20 \%$ & 413.18 & $\mathrm{nC}_{25}-\mathrm{nC}_{30}$ \\
$30 \%$ & 431.04 & $\mathrm{nC}_{30}-\mathrm{nC}_{31}$ \\
$40 \%$ & 449.88 & $\mathrm{nC}_{31}-\mathrm{nC}_{32}$ \\
$50 \%$ & 472.67 & $\mathrm{nC}_{32}-\mathrm{nC}_{34}$ \\
$60 \%$ & 494.51 & $\mathrm{nC}_{34}-\mathrm{nC}_{35}$ \\
$70 \%$ & 518.57 & $\mathrm{nC}_{36}-\mathrm{nC}_{37}$ \\
$80 \%$ & 547.05 & $\mathrm{nC}_{38}-\mathrm{nC}_{39}$ \\
$90 \%$ & 586.37 & $\mathrm{nC}_{39}-\mathrm{nC}_{2}$ \\
Final Boiling Point & 696.48 & $\mathrm{nC}_{43+}$ \\
\hline
\end{tabular}


Table 3. Elemental C, H, N, S percent analyses for FTS paraffins.

\begin{tabular}{cc}
\hline Material & FT Residue \\
\hline C, \% & 84.5 \\
H, \% & 14.7 \\
N, ppm & 83.2 \\
S, ppm & 29.6 \\
H/C ratio & 2.07 \\
\hline
\end{tabular}

The ASTM D7169 analysis method was used for the SIMDIS of the waxes.

The elemental analysis $(\mathrm{C} / \mathrm{H})$ was carried out by the elemental analyzer FLASH 2000 (ASTM D5291-The American Society for Testing and Materials: Standard Test Methods for Instrumental Determination of Carbon, Hydrogen, and Nitrogen in Petroleum Products and Lubricants), the nitrogen and sulfur content in microscale (ppm) was measured by the Trace SN Cube Instrument (ASTM D5453 and ASTM D4629, the American Society for Testing and Materials-Standard Test Method for Determination of Total Sulfur in Light Hydrocarbons, Spark Ignition Engine Fuel, Diesel Engine Fuel, and Engine Oil by Ultraviolet Fluorescence and Standard Test Method for Trace Nitrogen in Liquid Hydrocarbons by Syringe/Inlet Oxidative Combustion and Chemiluminescence Detection, respectively).

Paraffins and rendered fat $(0.4 \mathrm{mg})$ were pyrolyzed to evaluate the yields to ethylene and propylene. The samples were pyrolyzed in a Pyrolysis-GC/FID Multi-Shot Pyrolyzer ega/py-3030d using an Autoshot sampler AS-1020E. Gases were analyzed with GC-FID Shimadzu GC-2010 Plus.

The GC-FID was calibrated previously to the tests to identify and quantify the compounds in the product.

The effect of the temperature on the pyrolysis product distribution was studied. Heavy wax fractions from the FTS synthesis (fractions from distillation above $360{ }^{\circ} \mathrm{C}$ ) were mixed with 2,4 , and $8 \%$ of paraffins obtained after hydrolysis and hydrodeoxygenation of rendered fat (Figure 1). The mixtures were then pyrolyzed at 785,800 , and $815{ }^{\circ} \mathrm{C}$ (Supplementary Materials).

Data from the test served to build the response surface methodology using two variables (temperature and amount of animal fat added to FTS paraffins). RSM was used to carry out the tests according to the literature [23]. Least-squares were used in the fitting of the dependent variable, which for the present study was either total ethylene or propylene content yield. The used variables and coded factors are shown in Table 4.

Table 4. The response surface methodology (RSM) plan for pyrolysis tests. Pyrolysis test conditions (variables: Temperature from 785 to $815^{\circ} \mathrm{C}$ and $\mathrm{RF}$ amount in the mixture from 2 to $8 \mathrm{wt} \%$.

\begin{tabular}{ccccc}
\hline \multirow{2}{*}{ Test Name } & \multicolumn{2}{c}{ Natural Variables } & \multicolumn{2}{c}{ Coded Factors } \\
\cline { 2 - 5 } & Temperature, $^{\circ} \mathbf{C}$ & $\mathbf{R F}, \mathbf{w t} \%$ & $\mathbf{Z}_{\mathbf{1}}$ & $\mathbf{Z}_{\mathbf{2}}$ \\
\hline 1 & 785 & 2 & - & - \\
2 & 815 & 2 & + & - \\
3 & 785 & 8 & - & + \\
4 & 815 & 8 & + & + \\
5 & 800 & 4 & $=$ & $=$ \\
6 & 800 & 4 & $=$ & $=$ \\
7 & 800 & 4 & $=$ & $=$ \\
8 & 800 & 4 & $=$ & $=$
\end{tabular}

$Z_{1}$ This is the coded factor for the Temperature; $Z_{2}$ This is the coded factor for the content of rendering fat in the feedstock; + Maximum selected value; - Minimum selected value; = Mean between the maximum and the minimum selected values.

After performing the tests, the information data was (ethylene and propylene amounts) correlated using the Excel solver (Microsoft Office Excel 2016) with a similar method published in the literature $[23,24]$. The effect of the $\%$ RF added into the feedstock mixture and 
the reaction temperature were studied. In the present work, all the $\mathrm{k}$ factors $\left(\mathrm{x}_{\mathrm{i}}, \mathrm{i}=1\right.$ to $\left.\mathrm{k}\right)$ represent chosen quantitative variables affecting the unknown system response $Y$ [23].

In our case, the experimental values were used to obtain theoretical values using an equation type $\mathrm{y}(\mathrm{x})=\mathrm{A}+\mathrm{Bx}_{1}+\mathrm{Cx}_{2}+\mathrm{Dx}_{1} \mathrm{x}_{2}+\mathrm{Ex}_{1}{ }^{2}+\mathrm{Fx}_{2}{ }^{2}$, where $\mathrm{y}(\mathrm{x})$ is the $\mathrm{wt} \%$ of ethylene or propylene, $x_{1}$ is the temperature of the reaction, and $x_{2}$ is the amount of RF present in the raw mixture. According to the equation, the values A, B, C, D, E, and F can be calculated by selecting the gradient method in Excel solver and, as much as possible, the minimum of the difference between the experimental values and the new theoretical values obtained by the equation (options available in the software of the Excel Solver tool). The correlation coefficient, R, a good indicator of model fitting was obtained by the square root of the quadratic sum of the considered values divided by the quadratic sum of the experimental values. For each value, the percent error was calculated by subtracting the experimental value from the obtained value and then dividing the resulting value by the experimental value. Finally, the obtained number was multiplied by 100 . The sum of squares of the experimental deviations was also calculated.

The effect of the feedstock composition on the pyrolysis product distribution was also studied. The second group of tests was carried out after selecting the best temperature with the best yield to ethylene and propylene. Heavy wax fractions from FTS were mixed with rendered fat in the following concentrations: $0,10,20,30,40,50,60,70,80,90$, and $100 \%$.

\section{Results and Discussion}

The GC-FID pyrolysis results for the first group of tests are shown in Table 5. According to RSM, the frontier values of temperature and the amount of added animal fat were used to calculate the respective equations for ethylene and propylene.

Table 5. The gas chromatography with flame ionization detector (GC-FID) results. Percent errors for ethylene and propylene contents in the product ( $\mathrm{E}_{\text {ethylene }}$ and $\mathrm{E}_{\text {Propylene, }}$ respectively). Correlation coefficient for ethylene and propylene contents ( $R_{\text {Ethylene }}$ and $R_{\text {Propylene, }}$ respectively). Sum of squares of the experimental deviations (SSE Ethylene and SSE Propylene).

\begin{tabular}{|c|c|c|c|c|c|c|c|c|}
\hline Sample & 1 & 2 & 3 & 4 & 5 & 6 & 7 & 8 \\
\hline $\begin{array}{l}\text { Temperature, }{ }^{\circ} \mathrm{C}- \\
\text { RF content, wt } \%\end{array}$ & $785-2$ & $815-2$ & $785-8$ & $815-8$ & $800-4$ & $800-4$ & $800-4$ & $800-4$ \\
\hline Methane & 4.90 & 3.94 & 5.35 & 5.98 & 5.49 & 5.12 & 5.50 & 5.82 \\
\hline Ethane & 1.45 & 2.77 & 3.72 & 3.47 & 4.23 & 4.02 & 3.88 & 4.30 \\
\hline Ethylene & $\underline{8.85}$ & $\underline{29.94}$ & $\underline{24.53}$ & $\underline{28.74}$ & $\underline{23.82}$ & $\underline{23.04}$ & $\underline{25.24}$ & $\underline{25.21}$ \\
\hline$\overline{\text { Propane }}$ & $\overline{0.80}$ & $\overline{0.75}$ & $\overline{0.72}$ & $\overline{0.61}$ & 0.95 & 0.98 & $\overline{0.74}$ & 0.92 \\
\hline Propylene & $\underline{12.49}$ & $\underline{16.03}$ & $\underline{14.82}$ & $\underline{15.81}$ & $\underline{14.95}$ & $\underline{14.29}$ & $\underline{15.32}$ & $\underline{15.76}$ \\
\hline$\overline{\text { Acethylene }}$ & 0.01 & 0.01 & 0.09 & 0.21 & 0.10 & 0.08 & 0.12 & 0.11 \\
\hline iso-butane & 0.06 & 0.10 & 0.07 & 0.12 & 0.07 & 0.07 & 0.09 & 0.08 \\
\hline Propadiene & 0.23 & 0.18 & 0.17 & 0.12 & 0.21 & 0.23 & 0.16 & 0.20 \\
\hline n-butane & 0.01 & 0.01 & 0.01 & 0.01 & 0.01 & 0.01 & 0.01 & 0.01 \\
\hline t-2-butene & 0.00 & 0.00 & 0.18 & 0.25 & 0.17 & 0.00 & 0.22 & 0.18 \\
\hline 1-butene & 6.6 & 7.76 & 6.10 & 6.27 & 6.15 & 6.33 & 6.50 & 6.38 \\
\hline i-butene & 0.18 & 0.10 & 0.30 & 0.30 & 0.33 & 0.30 & 0.31 & 0.33 \\
\hline c-2-butene & 0.22 & 0.36 & 0.36 & 0.34 & 0.39 & 0.36 & 0.35 & 0.39 \\
\hline butadiene & 5.30 & 7.08 & 6.04 & 6.95 & 6.19 & 5.99 & 6.45 & 4.00 \\
\hline $\mathrm{C}_{6}-\mathrm{C}_{7}$ & 26.30 & 25.35 & 29.74 & 26.38 & 28.67 & 28.81 & 28.55 & 29.71 \\
\hline Toluene & 0.0 & 0.15 & 1.07 & 0.59 & 1.07 & 1.25 & 0.98 & 0.98 \\
\hline$C_{7+}$ and others & 32.6 & 5.45 & 6.74 & 3.85 & 7.19 & 9.13 & 5.60 & 5.63 \\
\hline EPropylene & 0.00 & 0.00 & 0.00 & 0.00 & 2.10 & 5.65 & -3.57 & -3.57 \\
\hline RPropylene & \multirow{2}{*}{\multicolumn{8}{|c|}{$\begin{array}{l}0.99 \\
3.56\end{array}$}} \\
\hline SSE $_{\text {Propylene }}$ & & & & & & & & \\
\hline $\mathrm{E}_{\text {Ethylene }}$ & 0.03 & -0.03 & -0.01 & 0.01 & 0.84 & 5.53 & -1.55 & -4.30 \\
\hline $\mathbf{R}_{\text {Ethylene }}$ & \multirow{2}{*}{\multicolumn{8}{|c|}{$\begin{array}{l}0.99 \\
1.16\end{array}$}} \\
\hline SSEEthylene & & & & & & & & \\
\hline
\end{tabular}


RSM was a useful tool to explore the production of ethylene and propylene. The amounts of ethylene, according to the addition of RF or changing the temperature, were variating according to the equation obtained for the ethylene and propylene contents. The product in Figures 2 and 3 , with respect to the other products, refers to $y(x)=A+B x_{1}+C x_{2}+D_{1} x_{2}+E_{1}{ }^{2}$ $+\mathrm{Fx}_{2}{ }^{2}$, where $\mathrm{y}(\mathrm{x})$ is the $\mathrm{wt} \%$ of ethylene with respect to the other products obtained after the pyrolysis, $x_{1}$ is the temperature of the reaction, and $x_{2}$ is the amount of RF present in the raw mixture. In this case, $\mathrm{A}=1.067, \mathrm{~B}=0.863, \mathrm{C}=78.497, \mathrm{D}=-0.092, \mathrm{E}=0.001$, and $\mathrm{F}=-0.354$ were the values for the ethylene results (Figure 2).

Theoretical value - Experimental value (wt\% - wt \%)

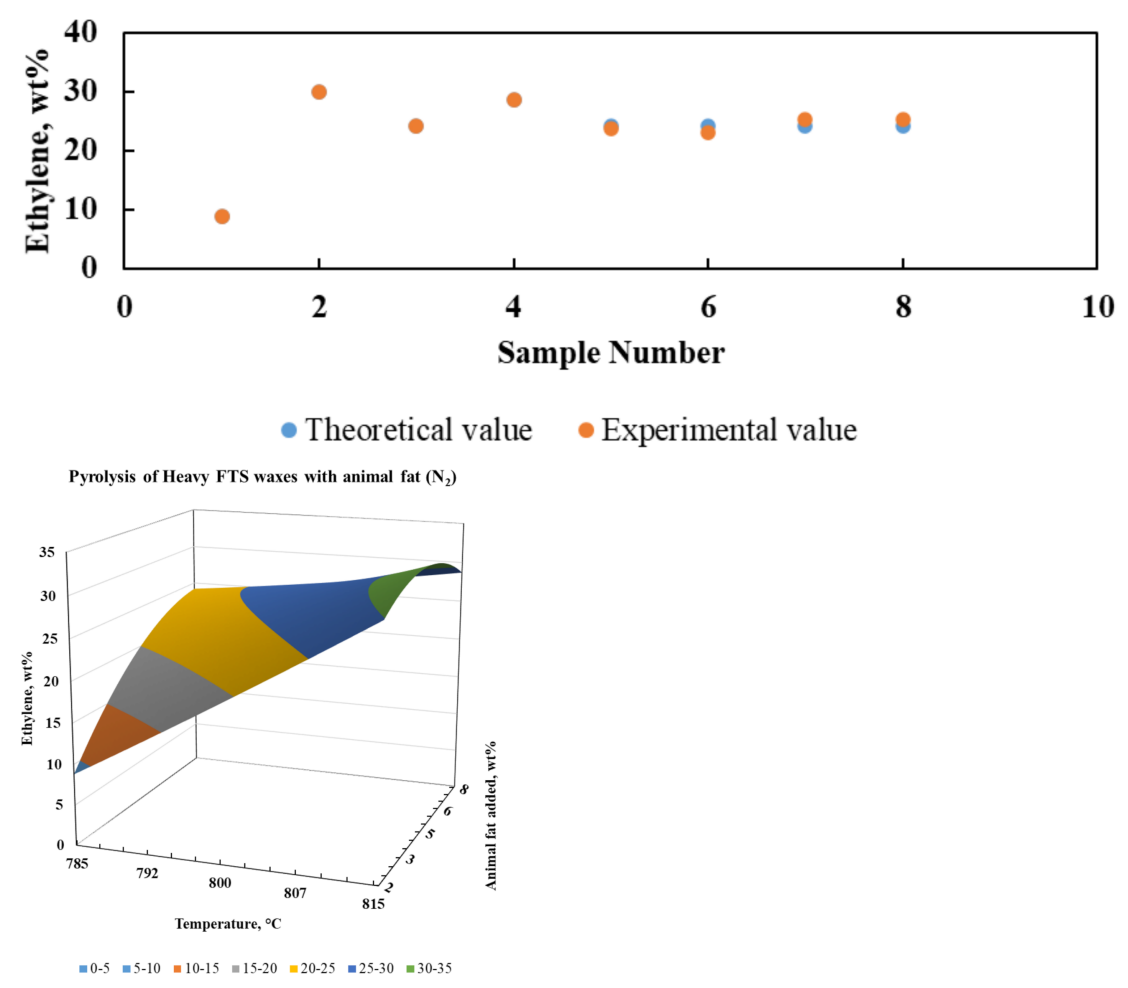

Figure 2. Theoretical and experimental difference values for the ethylene content in the product and the response surface for the tests with heavy FTS waxes.

For the propylene results, the $\mathrm{A}, \mathrm{B}, \mathrm{C}, \mathrm{D}, \mathrm{E}$, and $\mathrm{F}$ values were the next ones: $\mathrm{A}=1.074$, $\mathrm{B}=-0.115, \mathrm{C}=11.886, \mathrm{D}=-0.014, \mathrm{E}=0.0002$, and $\mathrm{F}=-0.065$ (Figure 3).

The regression coefficient was near 1 (Table 5 ) and the percent errors were variating from zero to 5.65 (maximum value) or -4.30 (minimum value). In addition, the theoretical values were similar to the experimental values for ethylene and propylene (Figures 2 and 3). Therefore, the RSM was a useful tool to select the optimum parameters, according to the system-reactor possible conditions of the reaction (the temperature and animal fat were added in this case).

According to the obtained results (Figures 2 and 3), the production rate of ethylene and propylene increased with the addition of animal fat when the temperature was $785^{\circ} \mathrm{C}$. However, when the temperature was $815^{\circ} \mathrm{C}$, the variation in the ethylene or propylene contents was not clear. When the temperature increased from 785 to $815^{\circ} \mathrm{C}$, the ethylene and propylene contents were higher. 
Theoretical value - Experimental value (wt $\%$ - wt \%)

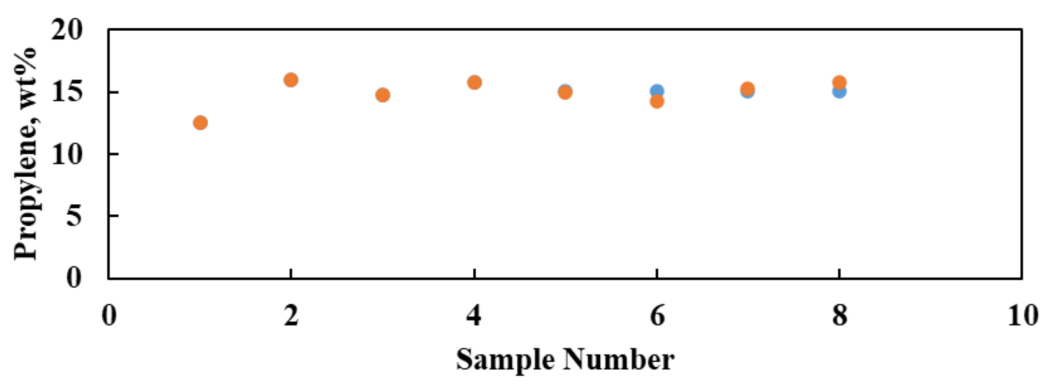

- Theoretical value Experimental value

Pyrolysis of Heavy FTS waxes with animal fat $\left(\mathbf{N}_{2}\right)$

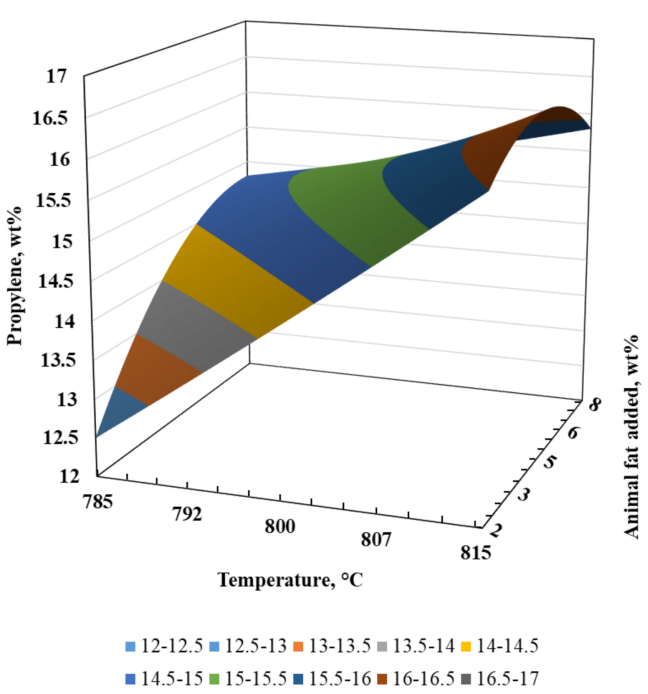

Figure 3. Theoretical and experimental difference values for the propylene content in the product and the response surface for the tests with heavy FTS waxes.

Considering these results, the temperature of $815^{\circ} \mathrm{C}$ was selected for the second group of tests. Although the feedstocks were different (paraffins from the HDO of animal fat and paraffins from the heavy FTS compared to animal fat and FTS paraffins mixtures directly), the maximum temperature was selected expecting a similar trend to the obtained ethylene and propylene due to the similarity of long-chain molecules as free fatty acids or long paraffins. Then, the tests using FTS paraffins with the addition of $0,10,20,30,40,50,60$, $70,80,90$, and $100 \%$ of animal fat were performed, and the obtained results are shown in Figure 4 . The ethylene concentration did not change signinigicantly by increasing the animal fat in the feedstock, while the propylene yield decreased slightly.

The tests performed at 785 and $815^{\circ} \mathrm{C}$ revealed that the yield of ethylene reached the maximum $(29 \%)$ at $815^{\circ} \mathrm{C}$. The yield of propylene as another interesting product reached $14 \mathrm{wt} \%$ at $815^{\circ} \mathrm{C}$. The increment of ethylene content by increasing the temperature (from 750 to $815^{\circ} \mathrm{C}$ ) was much higher than the increment of the propylene yield (Table 2).

Since no similar publications were dedicated to the fast pyrolysis of animal fat and heavy FTS fractions were found, the results and procedures reported in the present study can be considered as novel ones. In the industry, steam cracking is the most common way to produce ethylene and propylene, especially from crude oil [25]. Therefore, this study can be considered as a useful source of information in the decision to use animal fat and heavy FTS paraffins rather than crude oil sources for the production of ethylene, propylene, and other useful chemical compounds. 

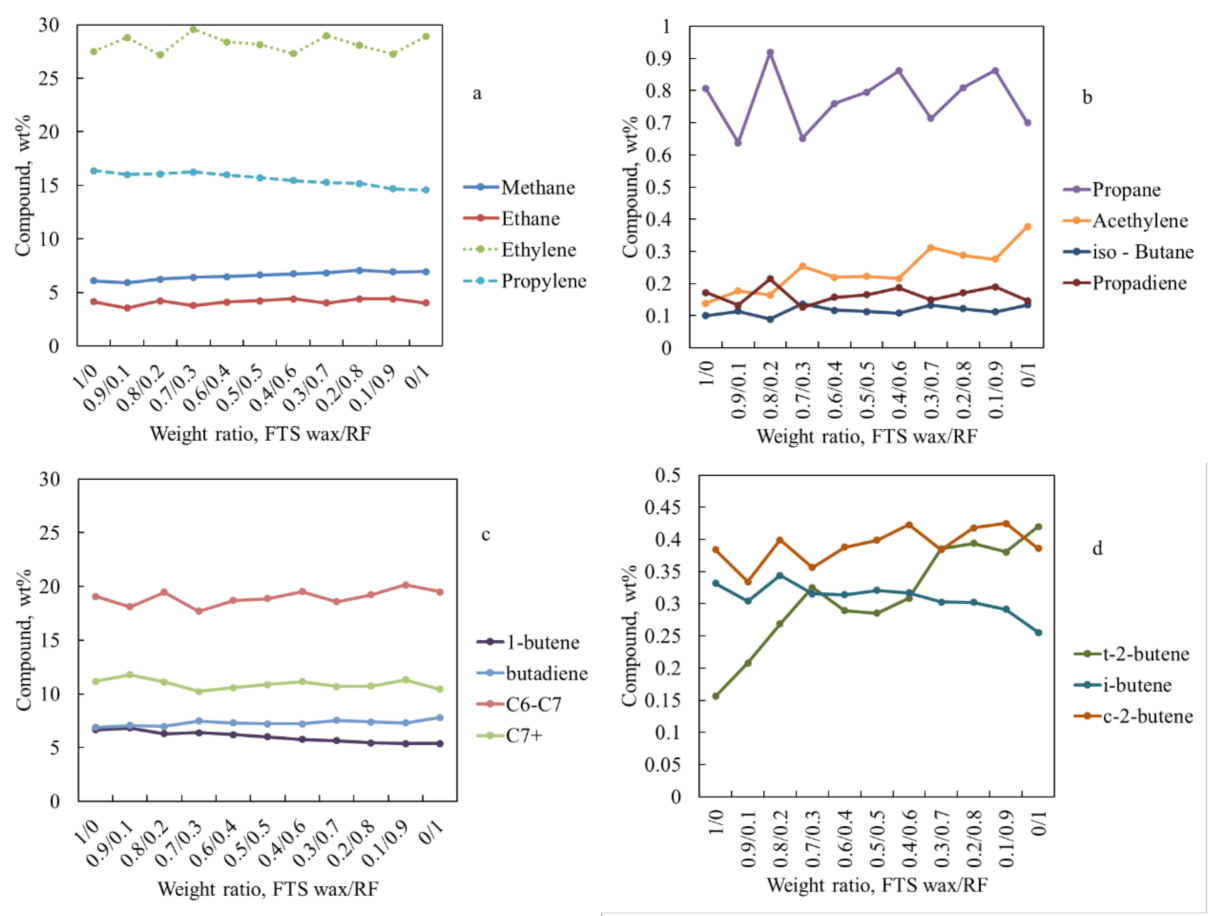

Figure 4. Product composition for pyrolysis tests containing different FTS waxes/RF ratios.

The mechanisms of the pyrolysis of waxes and triglycerides have been studied extensively in fuels and gases production $\left(\mathrm{C}_{1}-\mathrm{C}_{4}\right.$ products). The pyrolysis of triglycerides in this case was a non-catalytic direct thermal cracking having complex mixtures of oil products [26]. The results of this study provide information on the type of products that can be obtained at these temperatures $\left(785-815^{\circ} \mathrm{C}\right)$ without the use of a catalyst. The use of triglycerides, which are long-chain molecules as the FTS waxes, could explain the similarity of the results at $815^{\circ} \mathrm{C}$ obtaining similar amounts of ethylene and propylene. In addition, only some slight differences were found in the production of propylene. The mechanism of the triglyceride decomposition is explained first by the decomposition of the triglyceride, then the decomposition of the resultant fatty acids, acrolein, and ketenes. The fatty acids are then decomposed into carbon dioxide or carbon monoxide with the subsequent long-chain paraffins and olefins, which at high temperatures produced ethylene and propylene as the main products.

Regarding the reaction performed at $785^{\circ} \mathrm{C}$ and the low amount of $\mathrm{C}_{6}-\mathrm{C}_{7}$ compounds and ethylene compared to the other tests, it can be explained by the higher amount of $\mathrm{C}_{7+}$ products. Thus, at a lower temperature, the results were more sensible to the content of triglycerides in the feedstock, indicating that possibly the ethylene formation (and the lower increment of propylene content in the product) could be due to the acrolein and ketenes decomposition [26]. At higher temperatures $\left(815^{\circ} \mathrm{C}\right)$, the paraffins were decomposed in lower chain paraffins and subsequently into ethylene, propylene, and other olefins generating a similar amount of ethylene and propylene in the product.

\section{Conclusions}

The response surface methodology was found to be a useful tool to explore the yields of ethylene and propylene using the fast pyrolysis method. The experimental and theoretical results led to predicting the final production of ethylene and propylene contents. The addition of animal fat to heavy waxes resulted in similar yields to ethylene and propylene at $815^{\circ} \mathrm{C}$. Therefore, the animal fat could be used directly as feedstock for fast pyrolysis without the need to previously deoxygenate the fat. The ethylene content in the product obtained at $785^{\circ} \mathrm{C}$ was lower compared to the content in the products obtained at higher temperatures. 
Supplementary Materials: The following are available online at https:/ /www.mdpi.com/2227-971 7/9/2/367/s1. Figure S1: Pictures obtained using a microscope LEICA CM2500 LED for the mixture of $50 w t \%$ of RF and $50 w t \%$ of FTS; Figure S2: Pictures obtained using a microscope LEICA CM2500 LED for RF; Figure S3: Pictures obtained using a microscope LEICA CM2500 LED for FTS; Table S1: Simulated Dis-tillation of the feedstock, rendering fat, HDO paraffins and FTS paraffins; Table S2: FTS + RF mixtures GC-FID results (pyrolysis at $\mathrm{T}=815^{\circ} \mathrm{C}$ ).

Author Contributions: Conceptualization, M.M. and J.M.H.-H.; methodology, M.M. and J.M.H.-H.; software, M.M. and J.M.H.-H.; validation, M.M., Z.G., V.T., D.R.-P., and J.M.H.-H.; formal analysis, M.M., Z.G., V.T., D.R.-P., and J.M.H.-H.; investigation, M.M.; resources, M.M.; data curation, M.M. and J.M.H.-H.; writing-original draft preparation, M.M., Z.G., and J.M.H.-H.; writing-review and editing, M.M., Z.G., V.T., D.R.-P., and J.M.H.-H.; visualization, M.M. and J.M.H.-H.; supervision, M.M., V.T., and J.M.H.-H.; project administration, V.T.; funding acquisition, J.Š. and V.T. All authors have read and agreed to the published version of the manuscript.

Funding: This publication is a result of the project CATAMARAN, Reg. No. CZ.02.1.01/0.0/0.0/ 16_013/0001801, which has been co-financed by the European Union from the European Regional Development Fund through the Operational Programme Research, Development and Education. This project has also been financially supported by the Ministry of Industry and Trade of the Czech Republic, which has been providing institutional support for long-term conceptual development of research organisation. The result was achieved using the infrastructure of the project Efficient Use of Energy Resources Using Catalytic Processes (LM2018119), which has been financially supported by MEYS within the targeted support of large infrastructures.

Informed Consent Statement: Not applicable.

Data Availability Statement: MDPI Research Data Policies.

Conflicts of Interest: The authors declare no conflict of interest.

\section{References}

1. European Comission. Energy Roadmap_Impact Assessment and Scenario Analysis; European Comission: Brussels, Belgium, 2011; pp. 1-192.

2. European Environment Agency. Share of Renewable Energy in Gross Final Energy Consumption in Europe; European Environment Agency: Copenhagen, Denmark, 2015.

3. U.S. Energy Information Administration. International Energy Outlook 2019 with Projections to 2050; U.S. Energy Information Administration, Office of Energy Analysis, U.S. Department of Energy: Washington, DC, USA, 2019.

4. Karaba, A.; Dvořakova, V.; Jan Patera, J.; Zamostny, P. Improving the steam-cracking efficiency of naphtha feedstocks by mixed/separate processing. J. Anal. Appl. Pyrol. 2020, 146, 104768. [CrossRef]

5. Hsu, C.S.; Robinson, P.R. Petroleum System and Occurrence. In Petroleum Science and Technology; Springer: Cham, Switzerland, 2019; pp. 67-82. [CrossRef]

6. Moreira, J.V. Steam Cracking: Kinetics and Feed Characterisation; Instituto Superior Tecnico: Lisbon, Portugal, November 2015. Available online: https:/ / fenix.tecnico.ulisboa.pt/downloadFile/1126295043834327/JVM_ExtendedAbstract.pdf (accessed on 25 January 2021).

7. Dupain, X.; Krul, R.A.; Makkee, M.; Moulijn, J.A. Are Fischer-Tropsch waxes good feedstocks for fluid catalytic cracking units? Catal. Today 2005, 106, 288-292. [CrossRef]

8. Fogassy, G.; Thegarid, N.; Schuurman, Y.; Mirodatos, C. The fate of bio-carbon in FCC co-processing products. Green Chem. 2012, 14, 1367-1371. [CrossRef]

9. Herink, T.; Belohlav, Z.; Zamostny, P.; Doskocil, J. Application of Hydrocarbon Cracking Experiments to Ethylene Unit Control and Optimization. Petrol. Chem. 2006, 46, 237-245. [CrossRef]

10. Hidalgo, J.M.; Tišler, Z.; Vráblík, A.; Velvarská, R.; Lederer, J. Acid-modified phonolite and foamed zeolite as supports for NiW catalysts for deoxygenation of waste rendering fat. React. Kinet. Mech. Cat. 2019, 126, 773-793. [CrossRef]

11. Karaba, A.; Rozhon, J.; Patera, J.; Hajek, J.; Zamostny, P. Fischer-Tropsch Wax from Renewable Resources as an Excellent Feedstock for the Steam-Cracking Process. Chem. Eng. Technol. 2020, 44, 329-338. [CrossRef]

12. Simacek, P.; Kubicka, D.; Pospisil, M.; Rubas, M.; Hora, L.; Sebor, G. Fischer-Tropsch product as a co-feed for refinery hydrocracking unit. Fuel 2013, 105, 432-439. [CrossRef]

13. Kang, J.; Ma, W.; Keogh, R.A.; Shafer, W.D.; Jacobs, G.; Davis, B.H. Hydrocracking and Hydroisomerization of $n$-Hexadecane, n-Octacosane and Fischer-Tropsch Wax Over a Pt $/ \mathrm{SiO}_{2}-\mathrm{Al}_{2} \mathrm{O}_{3}$ Catalyst. Catal. Lett. 2012, 142, 1295-1305. [CrossRef]

14. Wang, F.; Xu, J.; Ren, J.; Li, Y. Experimental investigation and modeling of steam cracking of Fischer-Tropsch naphtha for light olefins. Chem. Eng. Process. 2010, 49, 51-58. [CrossRef] 
15. Dennis, J.O.; Lei, G.D. High purity naphthas for the production of ethylene and propylene. World Intellectual Property. Organization Patent International Publication Number WO2004069961A2, 19 August 2004.

16. Zamostny, P.; Belohalv, Z.; Starkbaumova, L. A Multipurpose Micro-pulse Reactor for Studying Gas-phase Reactions. Chem. Biochem. Eng. Q. 2007, 21, 105-113.

17. Zamostny, P.; Belohlav, Z.; Starkbaumova, L.; Patera, J. Experimental study of hydrocarbon structure effects on the composition of its pyrolysis products. J. Anal. Appl. Pyrolysis 2010, 87, 207-216. [CrossRef]

18. Belohlav, Z.; Pavlik, D.; Herink, T.; Svoboda, P.; Zamostny, P.; Marek, J. Use of Pyrolysis Gas Chromatography for Evaluation of Thermal Cracking of Naphtha. Chem. Listy 2002, 96, 325-329.

19. Belohlav, Z.; Herink, T.; Lederer, J.; Marek, J.; Rachova, N.; Svoboda, P.; Zamostny, P.; Vojtova, D. Evaluation of pyrolysis feedstock by pyrolysis gas chromatography. Pet. Chem. 2005, 45, 118-125.

20. Smidrkal, J.; Belohlav, Z.; Zamostny, P.; Filip, V. Olefin production through pyrolysis of triacylglycerols. Lipid Technol. 2009, 21, 220-223. [CrossRef]

21. Zamostny, P.; Belohlav, Z.; Smidrkal, J. Production of olefins via steam cracking of vegetable oils. J. Resour. Conserv. Recycl. 2012, 59, 47-51. [CrossRef]

22. Murat, M.; Lederer, J.; Rodová, A.; Hidalgo Herrador, J.M. Hydrodeoxygenation and pyrolysis of free fatty acids obtained from waste rendering fat. Eclet. Quim. 2020, 45, 28-36. [CrossRef]

23. Pinto, F.; Paradela, F.; Gulyurtlu, I.; Ramos, A.M. Prediction of liquid yields from the pyrolysis of waste mixtures using response surface methodology. Fuel Process. Technol. 2013, 116, 271-283. [CrossRef]

24. Ganesamoorthi, B.; Kalaivanan, S.; Dinesh, R.; Naveenkumar, T.; Anand, K. Optimization Technique using Response Surface Method for USMW process. Procedia Soc. Behav. Sci. 2015, 189, 169-174. [CrossRef]

25. Amghizar, I.; Vandewalle, L.A.; Van Geem, K.M.; Marin, G.B. New Trends in Olefin Production. Engineering 2017, 3, 171-178. [CrossRef]

26. Maher, K.D.; Bressler, D.C. Pyrolysis of triglyceride materials for the production of renewable fuels and chemicals. Bioresour. Technol. 2007, 98, 2351-2368. [CrossRef] 